\author{
Tomasz Bernat \\ Faculty of Economics and Management \\ University of Szczecin \\ kontakt@tomaszbernat.pl \\ Agnieszka Maciejewska-Skrendo \\ Faculty of Physical Education and Health Promotion \\ University of Szczecin \\ maciejewska.us@wp.pl \\ Marek Sawczuk \\ Faculty of Physical Education and Health Promotion \\ University of Szczecin \\ sawczuk_marek@wp.pl
}

Abstract. Entrepreneurship is currently one of the most frequently raised issues in contemporary economies. Not only does it influence social well-being but also the behaviors of individuals. Against that background, an idea of the analysis of genetically conditioned entrepreneurship is introduced. A research hypothesis was formulated: the presence of a particular polymorphic form of a given gene in a given person's genetic material makes people be more inclined towards risky actions and be more entrepreneurial. Entrepreneurship is understood here as a tendency to start business, subject to many different entrepreneurship definitions. Considerations over very entrepreneurship are presented in the first place. Subsequently, the attitude towards risk in entrepreneurshipis explained. The genetic research will be presented at the end. In summary, fundamental relationships between these researches are determined.

Keywords: risk perception, genes, entrepreneurship

JEL Classification: D81, L26, Z19

\title{
ENTREPRENEURSHIP AND RISK
}

Undertaking the review of relevant academic literature it seems there are as many definitions of entrepreneurship as authors. However, it is worth noting that this term has evolved as a result of economic changes and presently, in effect, of prevailing globalization. Thereby, for operating organizations, which are 
forced to react quickly to unexpected changes, but also "to adapt to unpredicted outcomes of the predicted changes" (Timmons, 1999), motion and flexibility have become the key factors. Therefore, the environment itself creates entrepreneurship.

Entrepreneurship is also understood as an attitude of societies and institutions (organizations). Institutions built on the principles of entrepreneurship have totally different characteristics - their goal is to transform reality, manufacture something new, open up new opportunities, "transcend" the current state of affairs. Similarly, E. Otoliński (Otoliński, 1996) stated that it is a set of features which determine the actions of: teams of people, institutions, entire economy, in a particular way. On the other hand, entrepreneurship is the process of creating and building something new (Shane, Venkataraman 2000). A. Gaweł (Gaweł, 2005), treats entrepreneurship as a process which integrates opportunities and actions for socially responsible wealth in the light of mutual evolution of people with organization and its environment. Entrepreneurship is also considered in a broader context of conditionings, analyzed on three levels (Safin, 2004): higher sense of self (Bławat 2004), general and professional knowledge as well as imagination (Kwiatkowski, 2000).

From the methodological view point there is an inextricable link between the categories of entrepreneurship and entrepreneur (Kraśnicka, 2002). One cannot separate and relate entrepreneurship only to organization or only to a man. Therefore, it becomes essential to present entrepreneurship also as a process which chiefly aims: creating wealth, business and innovation, implementing changes and creating new work places, value and company growth as well as economic growth (Morris et al., 2003; Duda \& Gasior, 2014).

The above discussions on seeking the universal definition of entrepreneurship focus around such factors (Borowiecki, Siuta-Tokarska, 2008) as: finding new ideas, transforming the idea into the market effect, discovering new forms of resource allocation, evoking motivation among people, tendency towards risk, company's establisher's personality domination, creating the network of interdependencies with the environment, including people and processes or creating new values. It is difficult to assess which is the most important one. It is vital to perceive the relationship between the concept creation and action in the process of entrepreneurship (Hisrich, Peters 1992). A real entrepreneur has the ability to create or appreciate a new concept and subsequently connect it with an action leading to realization.

What is entrepreneurship in relation to man (Probst, et al., 2002)? Psychological attitude is, in the first place, the characteristics of entrepreneurial man. In psychology, it is treated as a collection of psychological features of an individual considered to be entrepreneurial. The main psychological theories and concept distinguish personality, way of thinking, motivations, locus of control, attitude towards risk, its perception and assessment as the research subject .

However, entrepreneurial man is characterized as a person constantly proposing new ideas, who is not satisfied with current situation. Entrepreneurial person is capable of setting specific goals together with particular tasks related to them for himself and others as well as organizing their successful realization (Janik, 2001). Entrepreneurial people are individuals or groups of individuals who have four basic features: they connect various markets, they can function at malfunctioning markets, they can obtain needed resources and develop them (Leibenstein, 1968). Entrepreneurship is an activity necessary for starting up and running a business under market uncertainty or vague markets.

The term of market uncertainty or malfunctioning market appears here. Therefore, such an important feature as the inclination to take risks should be emphasized while characterizing entrepreneurial people. A man who does not like (is afraid of) risks will not be entrepreneurial (Janik, 2001). The readiness to risk is the feature of entrepreneurial man. The tendency to take risk is not tantamount to readiness to take excessive (unjustified) risk. As P. F. Drucker points out "entrepreneurship is risky" because so few among the so-called entrepreneurs know what they are doing (Drucker, 1992). 
The issue of risk in entrepreneurial man's action has been noticed by many researchers in this field. Starting from F. Knight who was proving that entrepreneurial actions are conditioned by some form of uncertainty and risk, through L. Misse, A. Schumpetr, P. Drucker, Casson who emphasized that entrepreneurial individuals are characterized by higher than others capability to overcome risk (Murmann, Sardana, 2013; Colli, 2013; Korpysa, 2014).

Basing on the findings of the aforementioned authors, contemporary science defines entrepreneurial behavior as an action of individual risk-taking (Freiling, 2009). Therefore, these individuals, thanks to internal locus of the feeling of control, undertake enterprises in which they will have the opportunity to assess the risk of a given action precisely - the so-called heuristics of risk. Having those skills distinguishes entrepreneurial individuals from the remaining part of market decision-makers. The former are more responsible for the choices they make, they learn from their own experiences, gathering information and knowledge about the probability of a given task realization with greater and greater certainty and commitment. This ensures theym achieve success and satisfaction from meeting particular objectives under conditions of risk.

This approach is consistent with the theory of J. A. Timmons who distinguishes 6 main characteristics of entrepreneurial people, i.e.: the ability to act under risk and uncertainty, dynamism of actions, leadership skills, the ability to recognize opportunities, creativity, independence and individuals' capability to adapt to conditions as well as internal motivation (Byers et al. 1999). In a particular way the researcher emphasizes the entrepreneurial man's ability to overcome risk and uncertainty, which are connected with every activity . This assumption was one of the cornerstones in the model of entrepreneurial individual decision-making under risk (Pech, Cameron, 2006; Kuger 2000).

Personality characteristics are another immensely important determinant of entrepreneurial individual decision-making under risk. Possessing creativity, openness, readiness to action, tendency to take risk, willingness to accept new challenges guarantee entrepreneurial individual effectiveness of undertakings.

It also helps solve the appearing problems in dynamically changing reality (Proctor, 2002). At this stage, the heuristics of risk plays a vital role. It influences the achievement of certainty in success and feasibility of a given action by entrepreneur. It follows from the presented considerations that the analysis of human behavior under conditions of risk is an extremely important aspect in recognizing the nature of entrepreneurship. Inner characteristics, beside external factors, in particular the abilities connected with the heuristics of risk, exert decisive influence on its shape. Occurring heuristic processes cause entrepreneurial undertakings to be of creative nature, simultaneously ensuring their effectiveness.

\section{METHODOLOGY OF THE CONDUCTED RESEARCH}

The main goal was to conduct the research to determine the extent to which a genotype of an individual makes him \ her more or less entrepreneurial. The main hypothesis was formulated accordingly: The presence of a specific polymorphic form of a given gene in the given individual's genetic material makes people be more inclined to take risky actions and thus makes them more entrepreneurial.

The study consisted of 3 stages, obligatory for each participant. In the first place, an economic experiment was conducted, which was supposed to provide an answer to the question of the individual's attitude towards risk. The game performed by the experiment organizers determined the attitude towards risk the particular players had.

The next part of the study was a research survey, aimed chiefly at determining individual entrepreneurial features of the respondent. The survey was supposed to show people's attitude to problems connected with 
entrepreneurship and to determine the influence the surroundings and environment have on the entrepreneurial attitudes.

The final part of the study, linking all the works were genetic studies.

Oropharyngeal swabs were collected into sterile tubes directly from the study participants who agreed on taking part in the experiment. The isolation of DNA from the oropharyngeal epithelium cells was performed using standard set of GenElute Mammalian Geomic DNA Miniprep Kit (Sigma-Aldrich, USA) reagents, as stipulated in the manufacturer's recommendations.

In order to detect the chosen polymorphic forms in the D2R2 gene, in search of the alleles which are responsible for specific individual attitudes of the man, Real-Time PCR technique utilizing Taq-Man (Applied Biosystems, USA) molecular probes was used.

An experiment whose aim was to analyze the relationship between the inclination towards risk and the utility of the achieved game result was used in the first and second part of the study. It has been assumed that with rising level of risk the utility of the received prize increased. The issue of individual decision making in conditions of risk at changing utility was studied. The experiment consisted in drawing envelopes, where a colored card was hidden: green or red. The color of the card drawn decided on the win or loss. During the experiment (drawing and deciding on a given choice) there was a chance of gaining or losing the prize.

The experiment consisted of two stages determining the attitude towards the risk of the decisions made. Each of the participants was able to stop at the first stage or take a risk and go to the second stage of the experiment under condition of winning at the first stage of the experiment. However, the choice at the first stage conditioned the options of choice in the second stage. The full description of the experiment can be found in the paper of T. Bernat and others (Bernat et.al., 2014).

Within the survey, the technique of paper questionnaire was applied, comprising of two parts: sociodemographic questions and questions concerning the tendency to take risk. In the survey part 5 general and 14 specific questions were formulated. Due to the research objectives indicated in the article, one of them, regarding the risk assessment connected with starting up own business was used. In the course of studies, grouping was used which resulted in a three-step scale of risk level assessment: low risk, moderate and average risk, high risk and very high risk.

\section{RESEARCH OUTCOME}

Utilizing the presented methodology studies in the discussed scope were conducted. The respondents group consisted mainly of women - total $72 \%$ in the entire population.

The economic experiment was performed on this group. Its results were observed in two stages of the game: an attitude towards risk and an inclination to decrease or increase it, depending on the original decision (at the first stage). Graph 1 shows overall results of the first stage of the game.

The data presented in graph 1 indicate that the majority of the participants (56\%) has high attitude towards risk. It means that they are willing to make risky decisions. As can be seen from the analysis of the graph, merely $5 \%$ of the studied has an aversion towards risk, since only such a fraction of the people preferred the non-risky decision, that is a certain win in stage 1 . Assessing jointly this result, it ought to be confirmed again that the attitude towards high risk prevails in the studied group in relation to certain win as well as to small risk of decision. 


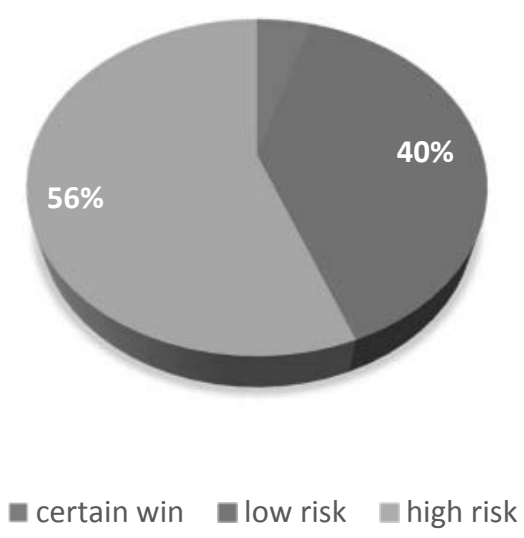

Graph 1. The attitude towards risk of the participants of the first stage of the economic experiment Source: own study.

Only 17 players agreed to participate in the second stage of the study. It is approximately $40 \%$ of all the participants of the game. A hypothesis may be formulated on this basis that the studied people did not want to take additional risk of the game, connected, among other things, with a possibility of higher win as well as with a loss of the win to date - over $60 \%$ of the experiment participants did that. Among the remaining people the results of the second stage of the game show reluctance to change their attitude to more risky. Graph 2 shows that.

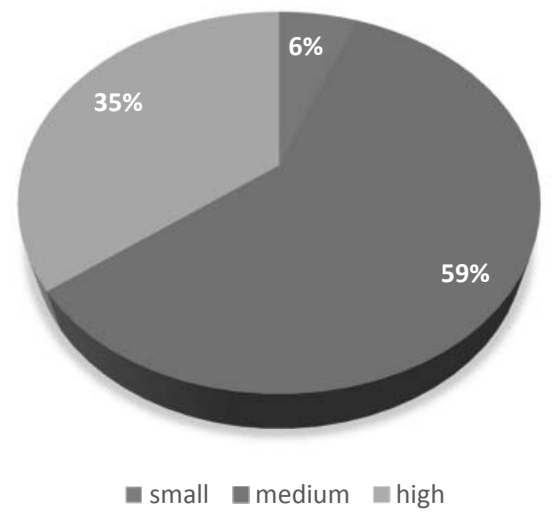

Graph 2. The choices of stage 2 of the economic experiment

Source: own study.

The results of the second stage show that the majority of the surveyed preferred to stay at small (6\%) or medium (59\%) risk. Only $35 \%$ of the players decided to take part in the most risky game. This provides evidence of not too large inclination to further risk taking among the players. Rather protective measures limiting the risk of loss were the reasons behind their behavior here. If only $35 \%$ of the respondents wanted 
to continue playing risky, in relation to $65 \%$ choosing either small or moderate risk, it may mean that making a decision at the first stage, merely high attitude towards risk (and possibility of winning) caused the players - both winners and losers to become unwilling to express further high risk. The losers from stage 1 may have been unwilling to continue losing, whereas the winners reluctant to lose what they had won, even at the cost of potentially higher win.

The survey was the second element of the study. Its results were supposed to allow the assessment of the individual attitude towards risk of the people participating in the experiment. Conditioning the selection of question with the possibility of verifying the formulated hypothesis, answers to questions concerning the respondents' current occupation, source of income and very attitude to starting up business will be presented.

In the first place respondents' current occupation will be presented in Graph 3

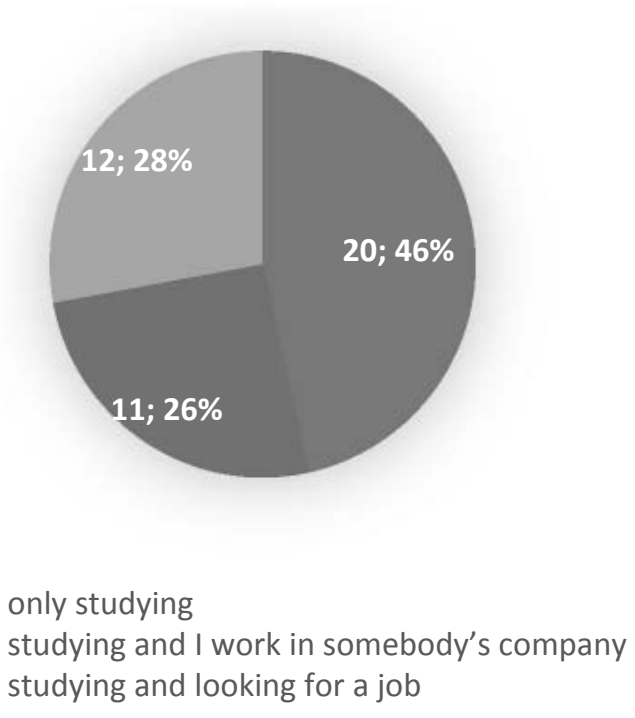

Graph 3. Respondents' current occupation

Source: own study.

The data presented in Graph 3 show that mere studying concerns less than a half of the respondents. Such answer was selected by $46 \%$ of the surveyed. A bigger part say they already work $(26 \%)$ or that they are actively looking for a job (28\%). Therefore, it may be stated that $54 \%$ of the surveyed could exhibits higher individual entrepreneurship since they undertook or undertake additional activities related to professional work (nevertheless, looking for a job is not consist with definition of entrepreneurship, but in this case can suggest higher entrepreneurial habits).

The analysis of the next question presented in Graph 4 clarifies the situation: I receive cash from my parents, part time job, full time job, scholarship 


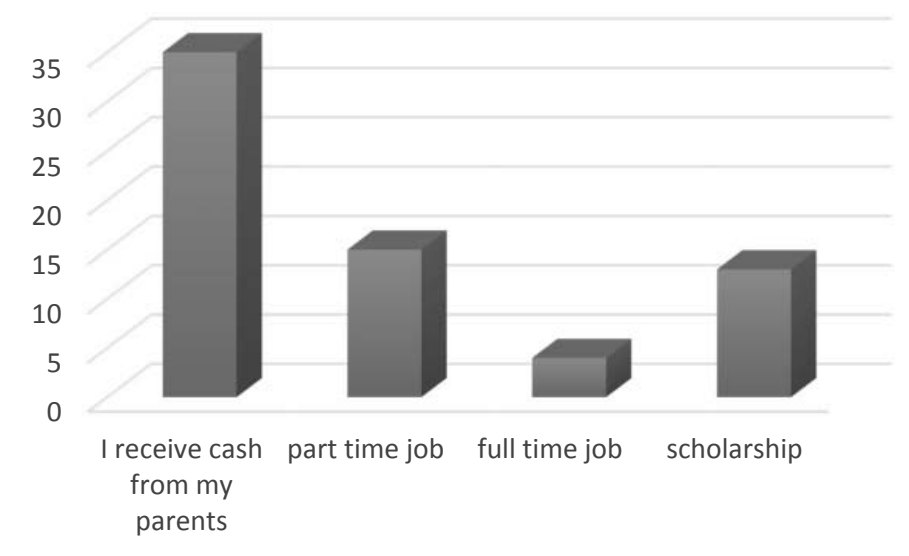

Graph 4. Income sources of the surveyed

Source: own study.

The data analysis from Graph 4 shows that only a fraction of the surveyed students indicate that their source income is their own salary (they could select more than one answer). Correspondingly these are 35\% of casual work and $9 \%$ full-time work - that is long-term connection with the employer. The majority of the respondents indicated that they receive subsistence support from their parents. Therefore, $81 \%$ of the surveyed have relatively easy and constant source of subsistence, which requires no individual resourcefulness in order to obtain the income. On the other hand, around $1 / 3$ of the respondents either have a job or are looking for it actively. Hence, this group of people should be characterized by higher individual resourcefulness. The last graph of this part shows the individual attitude of the surveyed towards the risk of starting up business.

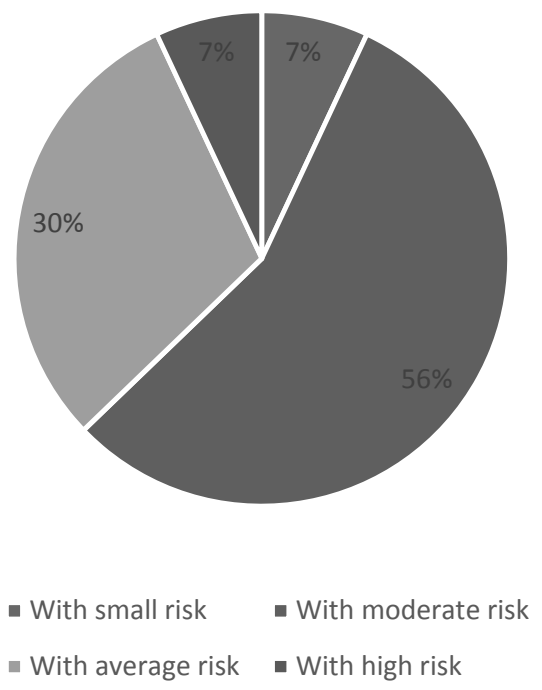

Graph 5. Assessment of the extent of risk connected with starting up and running a business Source: own study. 
The analysis of Graph 5 quite unambiguously shows that starting up business by the surveyed does not pose a big threat to them. $63 \%$ of the respondents (combined small and moderate risk) indicate that the level of risk is not as important to them, to become an obstacle in starting up business. However, the remaining $37 \%$ of the respondents declares that it is moderate or high risk, while $7 \%$ says it is of the highest level. The conclusion that can be reached from this analysis is that for the majority of students taking part in the experiment, starting up business is not connected with high risk. The results indicate that they are rational since the heaping majority treats starting up business as risky but they do not select extreme answers $-86 \%$ claim that it is of moderate or average risk. In the future it may result in them starting up business.

\section{CONCLUSION}

The goal of this very paper was the analysis of students' entrepreneurial behaviors in the context of three factors: risky attitudes, the assessment of the risk of stating up business and genetic predispositions. The part one have presented analysis of relation between entrepreneurial attitudes and risk. Attitudes were examined thought questionnaires and risk by experiment. The basic outcome is that majority of the participants (56\%) has high attitude towards risk. It means that they are willing to make risky decisions. The results of the second stage show that the majority of the surveyed preferred to stay at small (6\%) or medium (59\%) risk. Only $35 \%$ of the players decided to take part in the riskiest game. The conclusion that can be reached from this analysis of entrepreneurial behavior and risk attitudes is that for the majority of students taking part in the experiment, starting up business is not connected with high risk. Wider analysis of the relation between genes and students attitudes and behavior will be presented in part 2 .

\section{Ethics Statement}

The procedures followed in the study were conducted ethically according to the principles of the World Medical Association Declaration of Helsinki and ethical standards in sport and exercise science research. The procedures followed in the study were approved by the Ethics Committee of the Regional Medical Chamber in Szczecin. All participants were given a consent form and a written information sheet concerning the study, providing all pertinent information (purpose, procedures, risks, and benefits of participation). The potential participant had time to read the information sheet and the consent form. After ensuring that the participant had understood the information, every participant gave written informed consent (signed consent form) to genotyping on the understanding that it was anonymous and that the obtained results would be confidential. The experimental procedures were conducted in accordance with the set of guiding principles for reporting the results of genetic association studies defined by the Strengthening the Reporting of Genetic Association studies (STREGA) Statement (Little J, Higgins JP, Ioannidis JP, Moher D, Gagnon F, von Elm E, Khoury MJ, Cohen B, Davey-Smith G, Grimshaw J, Scheet P, Gwinn M, Williamson RE, Zou GY, Hutchings K, Johnson CY, Tait V, Wiens M, Golding J, van Duijn C, McLaughlin J, Paterson A, Wells G, Fortier I, Freedman M, Zecevic M, King R, Infante-Rivard C, Stewart A, Birkett N. "Strengthening the reporting of genetic association studies (STREGA): an extension of the STROBE Statement," Human Genetics, vol. 125, no. 2, pp. 131-151, 2009.). 


\section{REFERENCES}

Bernat, T., Gasior, A., Korpysa, J., Lakomy-Zinowik, M., Nagaj, R., \& Szkudlarek, P. (2014). Perception of the risk of starting up business and personal attitude to risk. Transformations in Business \& Economics, 13(2B), 780-800.

Bławat F., Konkluzje i rekomendacje badawcze, w: Zarządzanie przedsiębiorstwem, Bławat F. (red.), Scientific Publishing Group, Gdańsk 2004

Borowiecki R., B Siuta-Tokarska, Problemy funkcjonowania i rozwoju małych i średnich przedsiębiorstw w Polsce: synteza badań i kierunki działania, Centrum Doradztwa i Informacji Difin, Warszawa 2008

Byers T., Kist H., Sutton R.I. (1999), Characteristic of the entrepreneur: Social Creatures, Not Solo Heros, in: Technology Manager and Modern Context, red. R. C. Dorf, CRC and IEEE Press, Boca Raton, pp.3 - 5.

Colli, A. (2013) Family firms between risks and opportunities: a literature review., Socio-Economic Review 11.3, pp. $577-599$.

Drucker, P. (1992), Managing for the future, Truman Talley/ E.P. Dutton, New York, NY

Duda, J., \& Gasior, A. (2014). Innovation of Polish enterprises in the international arena. Transformations in Business \& Economics, 13(2B), 717-741.

Freiling, J. (2009), 'Uncertainty, innovation, and entrepreneurial functions: working out an entrepreneurial management approach', Int. J. Technology Intelligence and Planning, Vol. 5, No. 1, pp.22-35.

Friedman M, Savage LJ (1948) The Utility Analysis of Choices Involving Risk. The Journal of Political Economy 56: 279.

Gaweł A., Bariery rozwoju przedsiębiorczości w Polsce, Przegląd Organizacji nr 5/ 2005

Hisrich R. D., M. P. Peters, Entrepreneurship. Starting, Developing and Managing a New Enterprise, Second Edition, Irwing, Boston 1992

Janik W., Przedsiębiorczość i przedsiębiorstwo, WSPA, Lublin 2001

Korpysa, J. (2014). Schumpeterian entrepreneurship in academic spin off companies in Poland. Transformations in Business \& Economics, 13(3), 148-160.

Kraśnicka T., Wokół pojęcia przedsiębiorczości, Przegląd Organizacji nr 6 / 2002

Kwiatkowski S., Przedsiębiorczość intelektualna, PWN, Warszawa 2000

Leibenstein H., Entrepreneurship and Development, The American Economic Review, 58(2), 1968

Morris, Michael H., Nola N. Miyasaki, Craig E. Watters, and Susan M. Coombes. The Dilemma of Growth: Understanding Venture Size Choices of Women Entrepreneurs, Journal of Small Business Management vol. 44 / 2006

Murmann, J.P, Sardana D. (2013), Successful entrepreneurs minimize risk Australian Journal of Management 38.1, pp. 191-215.

Otoliński E., Istota I kreowanie przedsiębiorczości, Przegląd Organizacji nr 9/1996

Pech R.J., Cameron A. (2006), An entrepreneurial decision process model describing opportunity recognition, European Journal Innovation Management 2006, Vol. 9, No 1, p. 71

Probst, G. Managing Knowledge, Building Blocks for Success. Wiley. West Sussex, England, 2002.

Proctor T. (2002), Twórcze rozwiazywanie problemów, Wydawnictwo Uniwersytet Gdański, Gdańsk, pp. 62 - 64.

Safin K. Zarządzanie małą firmą, Wydaw. Akademii Ekonomicznej im. Oskara Langego, Wrocław 2004

Shane S. i S. Venkataraman, The Promise of Entreprenuership as a Field of Research, Academy of Management Review, Vol 25, No 1/2000

Timmons J.A., New Venture Creation: Entrepreneurship for the 21st Century, Irwin/McGraw-Hill, Boston 1999 